\title{
ELECTROLYTE IMBALANCE IN NEONATES WITH HYPOXIC ISCHEMIC ENCEPHALOPATHY: A SINGLE CENTER STUDY.
}

1. MBBS, MCPS, FCPS

Associate Professor Pediatrics

Allied Hospital/FMU, Faisalabad.

2. MBBS

Medical Officer Pediatrics

Allied Hospital, Faisalabad

3. MBBS, PGPN

Medical Officer Pediatrics

Govt General Hospital, Faisalabad.

4. MBBS

House Officer

Aziz Fatima Hospital, Faislabad.

5. MBBS, FCPS

Assistant Professor Pediatric

Emergency

Mayo Hospital, Lahore.

6. MBBS, MD

Medical Officer

Ashraf Naseer Medical Center,

Multan.

Correspondence Address:

Dr. Muhammad Shamaoon

Department of Pediatrics

Allied Hospital/FMU, Faisalabad.

mshamaoon@yahoo.com

Article received on:

21/09/2019

Accepted for publication:

04/03/2020

\section{INTRODUCTION}

Birth asphyxia in newborns during delivery has now become the major cause of metabolic abnormalities and neurologic injury. Perinatal mortality and incidence of neurological morbidity in neonates after birth have increased to an alarming extent in under developed and developing countries. Poor respiratory effort due to any reason during birth leads to perinatal asphyxia leading to brain hypoxia. ${ }^{1-2}$ The incidence of perinatal birth asphyxia is about 2-9 per 1,000 live births worldwide. Due to poor health facilities neonatal death rate with birth asphyxia is about $23 \%{ }^{2,3}$ A study by Waqas $\mathrm{T}$, et al reported the neonatal mortality rate of $64 \%$ after perinatal asphyxia in Pakistan (roughly 80,000 deaths/ year). ${ }^{1}$

American Academy of Pediatrics (AAP) defined perinatal asphyxia when: (1) Umbilical cord arterial blood pH less than 7; (2) Apgar score of 0 to 3 for longer than 5 minutes; (3) neonatal neurological manifestations (seizures, coma or hypotonia); and (4) Multisystem organ dysfunction e.g. cardiovascular, gastrointestinal, hematologic, pulmonary, or renal system. ${ }^{1,3}$ Perinatal asphyxia leads to hypoxic brain injury leading to hypoxic ischemic encephalopathy(HIE). ${ }^{1}$ According to Sarnat staging, HIE has three phases: Stage I(mild), Stage II (Moderate) and Stage III (extreme).2,4

Serum sodium, potassium and calcium changes in the human body can lead to major complications like convulsions. Imbalance of electrolytes including hypocalcemia, hyponatremia, hyperkalemia has been reported in perinatal birth asphyxia patients. Masood $\mathrm{N}$, et al reported the mean $+\mathrm{sd}$ of serum sodium $133.76+4.98 \mathrm{mg} / \mathrm{dl}$, serum potassium $4.82+0.62 \mathrm{mg} / \mathrm{dl}$ and serum 
calcium $8.68+0.70 \mathrm{mg} / \mathrm{dl}^{2}{ }^{2}$ Basu $P$ et al reported than mean serum sodium levels was significant lower $(122.1+6.0 \mathrm{mEq} / \mathrm{L}$, mean serum potassium was greater $(5.05+0.63 \mathrm{mEq} / \mathrm{L})$ and mean serum calcium level was longer $(6.85+0.95 \mathrm{mg} / \mathrm{dl})$ in asphyxia patients compared to controls. ${ }^{5}$

The basis of this investigation is that as the recurrence of neonates delivered with birth asphyxia leading to HIE is very high and no local data is available regarding the electrolyte changes in these patients, I have designed this study so that serum electrolyte levels during moderate HIE can be accessed. Early diagnosis and aggressive management of abnormal electrolyte changes can decrease the morbidity and mortality of neonates with perinatal asphyxia and HIE.

\section{MATERIAL \& METHODS}

To determine mean serum electrolyte levels in neonates with moderate hypoxic ischemic encephalopathy this detailed cross sectional research was done. Operational definitions included: Perinatal Birth Asphyxia: Neonates born with APGAR score delayed cry $<7$ at 5 min of birth was labeled as having perinatal asphyxia measured by the stopwatch. ${ }^{6}$ Moderate hypoxic ischemic encephalopathy (stage II): If a neonate is having any 3 of these signs; lethargy, hypotonia, flexed posture, weak neonatal reflexes (NNR), autonomic nervous system signs (miosis, bradycardia or periodic breathing), he/she was labeled as having moderate HIE (stage II). Serum electrolyte levels: Serum sodium level: Normal range 135 to $145 \mathrm{meq} / \mathrm{L}$; Serum calcium level: Normal range 7.5 to $10.0 \mathrm{meq} / \mathrm{L}$; Serum potassium level: Normal range 3.5 to $5.0 \mathrm{meq} / \mathrm{L}$. Study was done at the Neonatal emergency and labor room, Allied Hospital, Faisalabad.

Six months December 2017 to May 2018. The confirmation of synopsis Sampling was done using Non-probability consecutive sampling. The size of the sample was taken as 190 it was calculated using WHO sample size calculator with Test value population mean $=8.68^{2}$, Population standard deviation $=0.7^{2}$, confidence level $=95 \%$, absolute precision $=0.35$. All neonates of both gender, born at term (37-42 weeks of gestation) by either route meeting the operational definition of birth asphyxia and hypoxic ischemic encephalopathy (stage II) presenting within few minutes after birth were included in the study. All neonates with serum creatinine $>1.5 \mathrm{mg} /$ $\mathrm{dl}$, suspected metabolic disease or infants of mothers with hypertension, diabetes mellitus, toxemia of pregnancy; Neonates born to mothers who received general anesthesia; neonates with systemic visceral congenital malformations like congenital heart diseases; neonates born premature, born to diabetic mother, born with intrauterine growth retardation; neonates whose mothers received general anesthesia, or drugs that cause CNS depression in newborn like magnesium sulfate, pethidine, phenobarbitone, lithium or antiepileptic medication, mothers with history of febrile illness up to two weeks before delivery and mothers with abnormal serum electrolytes status pre and immediately postdelivery were excluded from the study.

After proper approval of the synopsis from the ethical review committee (ERC), neonates meeting the incorporation standard were enrolled in the study after proper legit approval from the parents. Each patient was evaluated by the primary investigator to access the grade of HIE after birth asphyxia and relevant data was collected. About $3 \mathrm{ml}$ cord blood sample was collected and sent to the pathology laboratory to check level serum calcium and serum electrolyte including sodium, potassium and chloride.

The analysis of data was done using SPSS version 20. Mean and standard deviation was calculated for quantitative variables like gestational age, weight, serum calcium, sodium and potassium level, APGAR score at 1 min and 5 min. Recurrence and percentage was determined for subjective factors like gender, delivered through history of fetal distress and type of HIE. Effect modifiers like gender, gestational age, weight APGAR score at 1 and 5 minutes, delivered through history of fetal distress and type of HIE were controlled through stratification. Post stratification independent sample $t$ test was adapted. $P$ value $<0.05$ was viewed as compelling. 


\section{RESULTS}

An aggregate of 190 cases satisfying the incorporation/rejection criteria were enlisted to decide the mean serum electrolyte level in neonates with perinatal birth asphyxia with moderate hypoxic ischemic encephalopathy.

Gestational age of the neonates was determined as $74.21 \% \quad(n=141)$ between $37-40$ weeks of gestation whereas $25.79 \% \quad(n=49)$ were between 41-42 weeks of gestation, mean +sd was calculated as $39.44+1.51$ weeks. (Table-l) Gender dispersion exhibits that $49.47 \%(n=94)$ were male and $50.53 \%(n=96)$ were females. (Table-II) Mean APGAR score at 1 minute was calculated as $4.59+0.49$ whereas $5.41+0.67$ at 5 minutes. (Table-III) Mean weight of the neonates was calculated as $2771.58+256.83$ grams. (Table-IV) Frequency of delivered through history of fetal distress was recorded in $43.68 \%(n=83)$ whereas $56.32 \%(n=107)$ had no fetal distress. (Table-V) Mean serum electrolytes shows that serum sodium $137.71+1.69 \mathrm{mg} / \mathrm{dl}$, serum potassium $3.92+0.18 \mathrm{mg} / \mathrm{dl}$ and serum calcium $8.45+0.51 \mathrm{mg} / \mathrm{dl}$. (Table-Vl) Effect modifiers like gender, gestational age, weight APGAR score at 1 and 5 minutes, delivered through history of fetal distress and type of HIE were controlled through stratification. Post stratification independent sample $t$ test was adapted. $P$ value $<0.05$ was viewed as compelling. Table-VII to XII.

\begin{tabular}{|l|c|c|}
\hline G. Age (in weeks) & No. of Patients & $\%$ \\
\hline $37-40$ & 141 & 74.21 \\
\hline $41-42$ & 49 & 25.79 \\
\hline Total & 190 & 100 \\
\hline Mean+SD & \multicolumn{2}{|c|}{$39.44+1.51$} \\
\hline
\end{tabular}

Table-l. G. Age of the neonates $(n=190)$.

\begin{tabular}{|l|c|c|}
\hline \multicolumn{1}{|c|}{ Gender } & No. of Patients & $\%$ \\
\hline Male & 94 & 49.47 \\
\hline Female & 96 & 50.53 \\
\hline Total & 190 & 100 \\
\hline
\end{tabular}

Table-II. Gender distribution $(n=190)$

\begin{tabular}{|l|c|c|}
\hline Apgar Score & Mean & SD \\
\hline 1 minute & 4.59 & 0.49 \\
\hline 5 minutes & 5.41 & 0.67 \\
\hline
\end{tabular}

Table-III. Mean APGAR score of the neonates $(n=190)$.

\begin{tabular}{|l|c|c|}
\hline Weight (grams) & \multicolumn{2}{c|}{ Mean } \\
\hline \multicolumn{2}{|c|}{2771.58} & \multicolumn{2}{c|}{256.83} \\
\hline \multicolumn{2}{|c|}{ Table-IV. Mean weight of the neonates $(\mathbf{n = 1 9 0 )}$} \\
\hline History of Fetal Distress & No. of Patients & $\%$ \\
\hline Yes & 83 & 43.68 \\
\hline No & 107 & 56.32 \\
\hline Total & 190 & 100 \\
\hline
\end{tabular}

Table-V. Frequency of delivered through history of fetal distress $(n=190)$.

\begin{tabular}{|l|c|c|}
\hline Serum Electrolyte & Mean & SD \\
\hline Sodium & 137.71 & 1.69 \\
\hline Potassium & 3.92 & 0.18 \\
\hline Calcium & 8.45 & 0.51 \\
\hline
\end{tabular}

Table-VI. Mean serum electrolyte level in neonates with perinatal birth asphyxia with moderate hypoxic ischemic encephalopathy $(n=190)$.

\begin{tabular}{|l|c|c|c|c|c|c|}
\hline \multirow{2}{*}{$\begin{array}{c}\text { Serum } \\
\text { Electrolyte }\end{array}$} & \multicolumn{2}{|c|}{$\mathbf{3 7 - 4 0}$ weeks } & \multicolumn{2}{c|}{$\mathbf{4 1 - 4 2}$ weeks } & \multicolumn{1}{c|}{ P- } \\
\cline { 2 - 6 } & Mean & SD & Mean & SD & Value \\
\hline Sodium & 137.72 & 1.61 & 137.67 & 1.92 & 0.85 \\
\hline Potassium & 3.91 & 0.18 & 3.94 & 0.17 & 0.39 \\
\hline Calcium & 8.48 & 0.53 & 8.37 & 0.45 & 0.20 \\
\hline
\end{tabular}

Table-VII. Stratification for mean serum electrolyte level in neonates with perinatal birth asphyxia with moderate hypoxic ischemic encephalopathy with regards to G.AGE $(n=190)$.

\begin{tabular}{|c|c|c|c|c|c|}
\hline \multirow{2}{*}{$\begin{array}{c}\text { Serum } \\
\text { Electrolyte }\end{array}$} & \multicolumn{2}{|c|}{ Male } & \multicolumn{2}{|c|}{ Female } & \multirow{2}{*}{$\begin{array}{c}\text { P- } \\
\text { Value }\end{array}$} \\
\hline & Mean & SD & Mean & SD & \\
\hline Sodium & 137.81 & 1.54 & 137.51 & 1.84 & 0.87 \\
\hline Potassium & 3.88 & 0.16 & 3.90 & 0.15 & 0.41 \\
\hline Calcium & 8.46 & 0.51 & 8.35 & 0.46 & 0.21 \\
\hline
\end{tabular}

Table-VIII. Stratification for mean serum electrolyte level in neonates with perinatal birth asphyxia with moderate hypoxic ischemic encephalopathy with regards to gender $(n=190)$.

\begin{tabular}{|l|c|c|c|c|c|c|}
\hline \multirow{2}{*}{$\begin{array}{c}\text { Serum } \\
\text { Electrolyte }\end{array}$} & \multicolumn{2}{|c|}{ Score 4 } & \multicolumn{2}{c|}{ Score 5 } & \multicolumn{1}{c|}{ P- } \\
\cline { 2 - 6 } & Mean & SD & Mean & SD & \\
\hline Vodium & 138.12 & 1.63 & 138.00 & 1.96 & 0.87 \\
\hline Potassium & 3.88 & 0.19 & 3.91 & 0.16 & 0.42 \\
\hline Calcium & 8.44 & 0.51 & 8.35 & 0.46 & 0.22 \\
\hline
\end{tabular}

Table-IX. Stratification for mean serum electrolyte level in neonates with perinatal birth asphyxia with moderate hypoxic ischemic encephalopathy with regards to apgar score at 1 minutes. $(n=190)$. 


\begin{tabular}{|l|c|c|c|c|c|c|}
\hline \multicolumn{1}{|c|}{$\begin{array}{c}\text { Serum } \\
\text { electrolyte }\end{array}$} & \multicolumn{2}{|c}{ Score 5 } & \multicolumn{2}{c|}{ Score 6 } & \multicolumn{1}{c|}{ P- } \\
\cline { 2 - 5 } & Mean & SD & Mean & SD & Value \\
\hline Sodium & 137.70 & 1.60 & 137.66 & 1.91 & 0.86 \\
\hline Potassium & 3.90 & 0.18 & 3.91 & 0.19 & 0.40 \\
\hline Calcium & 8.46 & 0.51 & 8.35 & 0.43 & 0.22 \\
\hline
\end{tabular}

Table-X. Stratification for mean serum electrolyte level in neonates with perinatal birth asphyxia with moderate hypoxic ischemic encephalopathy with regards to apgar score at 5 minutes. $(n=190)$

\begin{tabular}{|l|c|c|c|c|c|}
\hline \multirow{2}{*}{$\begin{array}{c}\text { Serum } \\
\text { Electrolyte }\end{array}$} & \multicolumn{2}{|c|}{$\begin{array}{c}\text { History of Fetal } \\
\text { Distress }\end{array}$} & \multicolumn{2}{c|}{$\begin{array}{c}\text { No History of } \\
\text { Fetal Distress }\end{array}$} & \multicolumn{1}{c|}{$\begin{array}{c}\text { P- } \\
\text { Value }\end{array}$} \\
\cline { 2 - 5 } & Mean & SD & Mean & SD & \\
\hline Sodium & 137.69 & 1.64 & 137.65 & 1.88 & 0.83 \\
\hline Potassium & 3.88 & 0.15 & 3.90 & 0.14 & 0.41 \\
\hline Calcium & 8.40 & 0.50 & 8.35 & 0.42 & 0.21 \\
\hline
\end{tabular}

Table-XI. Stratification for mean serum electrolyte level in neonates with perinatal birth asphyxia with moderate hypoxic ischemic encephalopathy with regards to delivered through history of fetal distress $(n=190)$.

\begin{tabular}{|l|c|c|c|c|c|}
\multirow{2}{*}{$\begin{array}{c}\text { Serum } \\
\text { Electrolyte }\end{array}$} & \multicolumn{2}{|c|}{$\begin{array}{c}\text { Upto } \mathbf{3 0 0 0} \\
\text { grams }\end{array}$} & \multicolumn{2}{c|}{$\begin{array}{c}\text { >3000 } \\
\text { grams }\end{array}$} & $\begin{array}{c}\text { P. } \\
\text { Value }\end{array}$ \\
\cline { 2 - 5 } & Mean & SD & Mean & SD & \\
\hline Sodium & 137.76 & 1.61 & 137.47 & 2.08 & 0.38 \\
\hline Potassium & 3.92 & 0.18 & 3.91 & 0.17 & 0.79 \\
\hline Calcium & 8.45 & 0.50 & 8.48 & 0.53 & 0.69 \\
\hline
\end{tabular}

Table-XII. Stratification for mean serum electrolyte level in neonates with perinatal birth asphyxia with moderate hypoxic ischemic encephalopathy with regards to weight $(n=190)$.

\section{DISCUSSION}

In perinatal period among neonatal problems the most common problem which increases neonatal mortality and morbidity significantly is Asphyxia. Through being present in all nations globally asphyxia is evaluated to represent in neonatal stage $23 \%$ of all the 4 million deaths and for stillbirth stage $26 \%$ of the 3.2 million deaths by the year. About one million kids, suffer asphyxia in perinatal stage, live with ingrained neuroformative sickness tallying cerebral paralysis, mental obstruction and distinctive in-capacities in learning. Hypoxic ischemic encephalopathy here directs to the (CNS) central nervous system dysfunction associated with perinatal asphyxia. The electrolyte imbalance manifests in the form of hyponatremia and hypocalcaemia which have critical direct relationship with seriousness of birth asphyxia.

This study was directed with the focus that as the frequency of neonates delivered with birth asphyxia leading to HIE is very high and no local data is available regarding the electrolyte changes in these patients, so we designed this study so that serum electrolyte levels during moderate HIE can be accessed. Early diagnosis and aggressive management of abnormal electrolyte changes can decrease the morbidity and mortality of neonates with perinatal asphyxia and HIE.

In our study, out of 190 cases, mean age was calculated as $39.44+1.51$ weeks, $49.47 \%(n=94)$ were male and $50.53 \%(n=96)$ were females. Mean APGAR score at 1 minute was calculated as $4.59+0.49$ whereas $5.41+0.67$ at 5 minutes. Mean weight of the neonates was calculated as $2771.58+256.83$ grams. Frequency of delivered through history of fetal distress was recorded in $43.68 \%(n=83)$, mean serum electrolytes shows that serum sodium $137.71+1.69 \mathrm{mg} / \mathrm{dl}$, serum potassium $3.92+0.18 \mathrm{mg} / \mathrm{dl}$ and serum calcium $8.45+0.51 \mathrm{mg} / \mathrm{dl}$.

A local study by MasoodN, et al reported the mean + sd of serum sodium $133.76+4.98 \mathrm{mg} / \mathrm{dl}$, serum potassium $4.82+0.62 \mathrm{mg} / \mathrm{dl}$ and serum calcium $8.68+0.70 \mathrm{mg} / \mathrm{dl} .{ }^{2} \mathrm{We}$ contrasted our outcomes and concluded that the results of our study are in concurrence with this study.

Basu $P$ et al reported than mean serum sodium levels was significant lower $(122.1+6.0 \mathrm{mEq} / \mathrm{L}$, mean serum potassium was higher $(5.05+0.63 \mathrm{mEq} / \mathrm{L})$ and mean serum calcium level was longer $(6.85+0.95 \mathrm{mg} / \mathrm{dl})$ in asphyxia patients compared to controls. ${ }^{5}$ Our findings are different with this study.

Jitendra Thakur and others ${ }^{7}$ determined the prevalence of electrolyte disturbances in perinatal asphyxia, they recorded that the mean values of sodium for mild, moderate and severe asphyxia were 135.52, 130.7 and $127.15 \mathrm{meq} / \mathrm{l}$ respectively. The values of potassium for mild, moderate and severe asphyxia were 4.96, 5.93 and $6.78 \mathrm{meq} / \mathrm{l}$ 
respectively. Similarly, the mean values of ionized calcium for mild, moderate and severe asphyxia were $1.07,1.12$ and $0.99 \mathrm{mmol} / \mathrm{l}$ respectively. The values of sodium and potassium among different severity of asphyxia were significantly different ( $p$-value $<0.001)$. Significant positive association was found between serum sodium and Apgar score at $5 \mathrm{~min}$. Critical negative association was accessible between serum potassium and Apgar score at $5 \mathrm{~min}$. They inferred that the level-o hyponatremia and hyperkalemia was directly proportional to the severity of birth asphyxia. So these electrolyte disturbances ought to consistently be remembered while overseeing instances of perinatal asphyxia and ought to be managed as needs be. Whereas, only stage II cases of HIE were included in our study.

Basu $\mathrm{P}$ etal ${ }^{8}$ observed in asphyxiated neonates that when contrasted with controls ( $p<0.001$ ) mean serum potassium level was higher. 18 Although, the serum potassium levels in our study were found to be increased in cases of birth asphyxia as compared to controls, but the levels remained within normal limits.

The limitation of our study was that we did not include a control group and the other limitation of our study was that the data was measured quantitatively which may not enable us to determine the frequency of hypocalcemia, hyponatremia and hyperkalemia in these cases. However, early diagnosis and aggressive management of abnormal electrolyte changes can decrease the morbidity and mortality of neonates with perinatal asphyxia and HIE.

\section{CONCLUSION}

We concluded that mean serum electrolyte level in neonates with perinatal birth asphyxia with moderate hypoxic ischemic encephalopathy were in normal range, however, in absence of control group and data analysis in qualitative way, we are unable to record the frequency of hypocalcemia, hyponatremia and hyperkalemia, which may be done in coming trials.

\section{Copyright $\subseteq 04$ Mar, 2020.}

\section{REFERENCES}

1. Waqar $\mathrm{T}$, Haque $\mathrm{KN}$. Birth asphyxia: Brief review of pathogenesis and pragmatic guidelines for its management in resource limited countries. Pak Paediatric J 2012; 36:61-9.

2. Masood N, Muntiha S, Sharif M, Asghar RM. Correlation of serum electrolyte changes with severity of birth asphyxia in newborns. Rawal Med Coll 2016; 20:27-9.

3. Seyal T, Hanif A. Factors related to adverse outcome in asphyxia babies. Ann King Edward Med Uni 2009; $15: 180-4$

4. Chapman IA, Stoll BJ. Nervous system disorders. In: Kliegman R, Nelson WE, editors. Nelson textbook of pediatrics. $19^{\text {th }}$ ed. Philadelphia: Saunders; 2012.p.5703.

5. Basu P, Som S, Das H, Choudhuri N. Electrolyte status in birth asphyxia. Indian J Pediatr 2010; 77:259-62.

6. Amritanshu K, Smriti S, Kumar V, Pathak A, Banerjee DP. Clinical profile and short term outcome of hypoxic ischemic encephalopathy among birth asphyxiated babies in Katihar Medical College Hospital. J Clin Neonatal 2014; 3:195-9.

7. Thakur J, BhattaNK, Singh RR, Poudel P. Prevalence of electrolyte disturbances in perinatal asphyxia: $A$ prospective study. Italian Journal of Pediatrics 2018; 44:56.

8. Basu P, Som S, Das H, Choudhuri N. Electrolyte status in birth asphyxia. Indian J Pediatr 2010; 77:259-62. 


\begin{tabular}{|c|c|c|c|}
\hline \multicolumn{4}{|c|}{ AUTHORSHIP AND CONTRIBUTION DECLARATION } \\
\hline Sr. \# & Author(s) Full Name & Contribution to the paper & Author(s) Signature \\
\hline 1 & Muhammad Shamaoon & $\begin{array}{l}\text { Data collection, Paper } \\
\text { writing. }\end{array}$ & \\
\hline 2 & Nadia Razzaq & $\begin{array}{l}\text { Data collection, Paper } \\
\text { writing. }\end{array}$ & Nodic \\
\hline 3 & Muhammad Ahsan & $\begin{array}{l}\text { Paper writing, Data entry, } \\
\text { Data analysis. }\end{array}$ & Afeer \\
\hline 4 & Arslan Ahmad & Data entry, Data collection. & Aptom \\
\hline 5 & Tehmina Maqbool & $\begin{array}{l}\text { Discussion writing, Data } \\
\text { entry. }\end{array}$ & Tehmy \\
\hline 6 & & $\begin{array}{l}\text { Data analysis, Discussion } \\
\text { writing. }\end{array}$ & Amanes \\
\hline
\end{tabular}

